\title{
Yield and morpho-physiological traits of tobacco (Nicotiana tabacum L.) as affected by azotobacter, mycorrhizal symbiosis and biochar application
}

\author{
Ramin Mesbah ${ }^{1}$, Mohammad Reza Ardakani ${ }^{*}$, Ali Moghaddam ${ }^{3}$ \& Farnaz Rafiei ${ }^{1}$ \\ ${ }^{1}$ Department of Agronomy, Tehran North Branch, Islamic Azad University, Tehran, Iran \\ ${ }^{2}$ Department of Agronomy, Karaj Branch, Islamic Azad University, Karaj, Iran \\ ${ }^{3}$ Seed and Plant Improvement Institute (SPII), Agricultural Research, Education and Extension Organization (AREEO), Karaj, Iran \\ *Email: mreza.ardakani@gmail.com
}

\section{ARTICLE HISTORY}

Received: 10 July 2021

Accepted: 03 October 2021

Available online: 13 November 2021

\section{KEYWORDS}

biochar

biofertilizer

rainfed

tobacco

yield

\begin{abstract}
The present study was performed to evaluate the effect of mycorrhizal symbiosis and azotobacter with the application of biochar on tobacco growth parameters, yield and nicotine content under rainfed conditions for two growing seasons (2016-2017 and 2017-2018). The factorial experiment was performed based on a randomized complete block design with four replications and three factors including biochar at three levels (0, 4 and 8 ton/ha), mycorrhizal fungi and Azotobacter chroococcum each one at two levels (without and with application). Results showed that biochar application had a significant and positive effect on all evaluated parameters. However, there was no statistically significant difference between 4 and 8 tons per ha of biochar in yield. Mycorrhizal symbiosis had a significant effect on relative water content. Application of azotobacter had a positive and significant effect on growth parameters, yield and nicotine content. The greatest effect of azotobacter with a $17 \%$ increase was on leaf nicotine content. Whereas tobacco dry yield in rainfed conditions is lower, the combined use of biochar and these biofertilizers can be considered a desirable solution. Then, in terms of economic aspects, the use of 4 tons biochar per ha along with the use of mycorrhiza and azotobacter to achieve acceptable yield while maintaining chemical quality in tobacco farms is recommended.
\end{abstract}

\section{Introduction}

Tobacco (Nicotiana tabacum L.) is an important industrial crop that, in addition to consumption in the tobacco industry, has various applications, including as a model plant in the field of biotechnology and nicotine extraction for the pharmaceutical industry (1). Although this plant is relatively tolerant to drought stress, studies have shown that to produce economically, it needs a water supply, especially in the rapid growth stage (2). To reduce the harmful effects of agrochemicals in tobacco leaf quality, using biofertilizers and natural-based compounds such as biochar are becoming among the important agroecological practices for plant production. Biochar is the carbon-rich material obtained by pyrolysis using various biomasses $(3,4)$. The application of biochar to improve the physical and chemical properties of soil has been considered (5). Biochar improves soil properties (soil physicochemical characteristics like $\mathrm{pH}$, CEC, soil structure), water holding capacity and immobilizes soil environmental pollutants $(6,7)$. It has been shown in several studies that the use of biochar increases plant growth and biomass and absorbs nutrients in water stress conditions (8-11). A study, applying different amounts of biochar on tobacco quality showed that consumption of 15 tons of biochar per ha by providing nutrients and soil moisture improved the tobacco leaf's quantitative and qualitative yield (12). Arbuscular mycorrhizal fungi (AMF) is a major component of the rhizosphere microflora in natural ecosystems (13). Mycorrhiza promotes plant water status and plays an important role in enhancing plant nutrition and yield (14). Mycorrhizal symbiosis develops root growth and improves access to water resources and nutrients in subterranean clover, which is an important support during water deficit stress (15). Under water stress conditions, mycorrhizal symbiosis with plant roots increases shoot growth and root development in the soil. Azotobacter is a group of free-living, nitrogen fixing aerobic bacteria living in the soil. These bacteria are known to fixate atmospheric nitrogen for

(C) Mesbah et al (2021). This is an open-access article distributed under the terms of the Creative Commons Attribution License, which permits unrestricted use, distribution and reproduction in any medium, provided the original author and source are credited (https://creativecommons.org/licenses/by/4.0/). 
their cellular protein synthesis, which is mineralized in the soil and transfers a significant portion of the nitrogen present from the soil source to plants (16). Azotobacter chroococcum is of particular importance due to its wide distribution in the soils and producing of different types of metabolites in the rhizosphere. Inoculation of the roots with this bacterium makes it resistant to drought stress (17). In general, biofertilizers such as azotobacter and mycorrhizal fungi improve vegetative growth and leaf development by providing phosphorus and nitrogen, and consequently increasing the yield and relative water content of leaves (18). Despite synthetic fertilizers efficiency in promoting crop yields, they have proved to be hazardous for soil health and the wellbeing of human and animal populations (19). Recent advances in agriculture are focused on reducing the use of inorganic fertilizers, to find alternative ways and improve crop yield in sustainable agriculture (20). The utility of microorganisms that improve soil fertility and enhance plant nutrition has continued due to the increase in the cost of chemical fertilizers and their negative impact on the environment. Plant growth promoting rhizobacteria (PGPR) play an important role in the mineralization and immobilization of nutrients needed for the growth of tobacco (21). In addition, mycorrhiza inoculum is available at a meager price with the possibility of replacement with chemical fertilizers can be considered an environmentally friendly solution. Biochar is currently an unknown compound in Iran, so its application on the yield and other properties of tobacco has not been studied. Due to the easy accessibility and low cost of supplying these two types of biofertilizers along with an application of biochar, this study was conducted.

\section{Materials and Methods}

\section{Research location specifications}

This study was carried out during the spring and summer seasons of 2017 and 2018 at experimental farm of Tirtash Tobacco Research and Education Center, located at $\left(44^{\circ} 53^{\prime} 22^{\prime \prime}-\mathrm{E} ; 36^{\circ} 42^{\prime} 12 \mathrm{~N}\right)$ in the north of Iran under rainfed conditions. According to 30 -year meteorological statistics, the average rainfall in the region is $622 \mathrm{~mm}$ per year. The average annual maximum temperature is in July $\left(30{ }^{\circ} \mathrm{C}\right)$ and the minimum temperature is in January $\left(5{ }^{\circ} \mathrm{C}\right)$. The amberotermic graph of the studied season is given in Fig. 1 and the results of soil analysis were performed in Table 1.

\section{Characteristics of biochar, azotobacter and mycorrhiza}

The scanning electron microscope (SEM) of biochar was performed in Razi Metallurgical Research Center (Fig. 2). Biochar chemical analysis is shown in Table 2. The mycorrhizal inoculum included three spices, Glomus mosseae, G. intraradices and G. etunicatum with a total population of 70 active fungal organs per $g$ of biological fertilizer (22). Azotobacter chroococcum inoculums contained the minimal bacterial density of $10^{7} \mathrm{CFU} / \mathrm{g}$ (23). Both the types of biofertilizers were prepared in the laboratories of the Soil and Water Research Institute of Iran.

\section{Plant materials and experimental design}

The flue-cured tobacco pellet seeds (Var. K326) were sown in the 220-cell trays with dimensions of $57 \times 37$ $\mathrm{cm}$. The seeds of this variety are produced in the Tirtash tobacco research and education center. In mycorrhizal treatments, each tray was filled with 2000 $\mathrm{g}$ of soil media mixed with $200 \mathrm{~g}$ of inoculum before sowing. In treatments containing Azotobacter chroococcum inoculum, ten days before transplanting, seedling's roots inoculated with an equal volume of inoculums and water solution for an hour. The biochar was scattered to the soil surface and then mixed to achieve a sufficiently mix with $20 \mathrm{~cm}$ depth soil. The tobacco transplanting and harvest were conducted in May and September (2017 and 2018) respectively. The experiment was performed as a factorial based on randomized complete block design (RCBD) with three factors including biochar (B) at three levels (B0: no biochar application, B4: application 4 ton/ha and B8 application 8 ton/ha), mycorrhizal fungi (M) at 2 levels, (M0: no mycorrhiza application and M1: mycorrhiza application) and azotobacter (A) at 2 levels, (A0: no azotobacter application and A1: azotobacter application) in 4 replications (nicotine \% in 3 replications).

\section{Growth parameter measurements}

After the end of vegetative growth, 5 plants were selected randomly in each experimental plot considering the border effect. The average number of leaves in the tobacco plant is about 25 leaves. The $13^{\text {th }}$ leaf of the plant was selected to measure growth parameters and chemical characteristics as an average of the whole plant. The length and width of the $13^{\text {th }}$ as the middle leaf have been measured in each experimental plot. To calculate the plant height before the flowering stage, the height of five plants was measured separately from the soil surface to the highest part of the plant aerial parts in $\mathrm{cm}$. Their average was recorded as the growth parameter of the plot.

\section{Relative water content (RWC)}

At the mid-growing season, RWC was measured using five $1 \mathrm{~cm} \times 1 \mathrm{~cm}$ surfaces of new fully expanded leaves of $13^{\text {th }}$ tobacco leave. At first, the fresh weight of samples was determined and then, samples were immersed in distilled water for 12 hrs in darkness. The turgid weight was measured. The leaf samples were oven-dried at $75{ }^{\circ} \mathrm{C}$ for $24 \mathrm{hrs}$ for calculating their dry weight. RWC was measured using the following equation (24):

RWC $=$ [(fresh weight - dry weight) / (turgid weight -DW dry weight)] $\times 100$.

\section{Dry yield}

Generally, in tobacco 3-4 leaves be harvested at a time, and then cured in bulk-curing based on virginia tobacco curing method. At the end of each harvesting and curing period, the tobacco leaves of each plot were weighed separately and the dry weight of tobacco of each plot was recorded as a dry leaf yield on the same plot.

\section{Mycorrhizal symbiosis}

After the last harvest, one root sample from each replication was isolated and colored by standard 


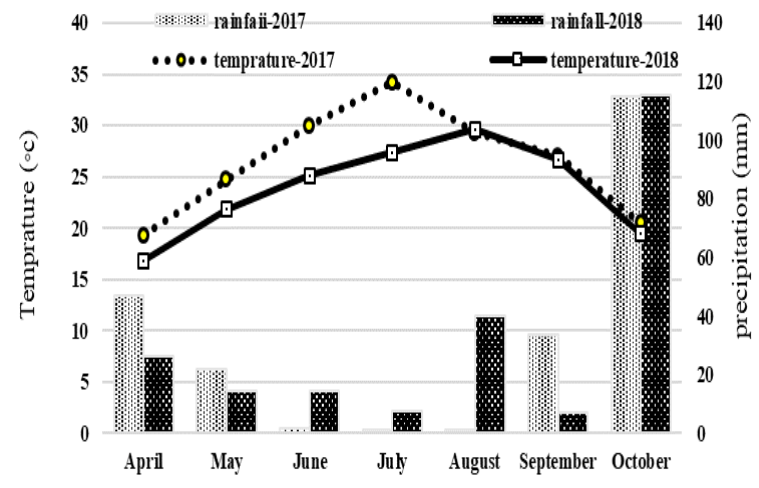

Fig. 1. Temperature and precipitation distribution (2017-2018).

\section{Results and Discussion}

\section{Growth parameters}

The main effect of biochar and azotobacter on plant height was positive and significant (Table 3). So that with increasing the level of biochar applied, growth parameter increased and each of the biochar levels was in different statistical groups (Table 4). Application of azotobacter also increased the leaf length by about $2.5 \mathrm{~cm}$, leaf width by $1 \mathrm{~cm}$ and plant height by $8 \mathrm{~cm}$ (Table 4). Application of mycorrhiza was significant only on leaf width at 5\% level (Table 3 ). The interaction effect of mycorrhiza $\times$ azotobacter on leaf length was significant at a 5\% level (Table 3). According to Fig. 3, the lowest leaf length was related to treatments with non-application of mycorrhiza and azotobacter. The interaction effect of biochar $\times$

Table 1. Some characteristics of farm soil

\begin{tabular}{cccccccccccc}
\hline $\begin{array}{c}\text { soil } \\
\text { characteristics }\end{array}$ & $\begin{array}{c}\text { Soil } \\
\text { texture }\end{array}$ & $\begin{array}{c}\text { Clay } \\
(\%)\end{array}$ & $\begin{array}{c}\text { Silt } \\
(\%)\end{array}$ & $\begin{array}{c}\text { Sand } \\
(\%)\end{array}$ & $\begin{array}{c}\text { Neutralizing } \\
\text { Matter (\%) }\end{array}$ & $\begin{array}{c}\text { Total } \\
\text { Nitrogen } \\
(\%)\end{array}$ & $\begin{array}{c}\text { Phosphorus } \\
(\mathrm{ppm})\end{array}$ & $\begin{array}{c}\text { Absorbable } \\
\text { Potassium } \\
(\mathrm{ppm})\end{array}$ & $\begin{array}{c}\text { Chloride } \\
(\mathrm{ds} / \mathrm{m})\end{array}$ & $\begin{array}{c}\text { Electrical } \\
\text { Conductivity } \\
(\mathrm{ds} / \mathrm{m})\end{array}$ & $\begin{array}{c}\text { Organic } \\
\text { Carbone } \\
(\%)\end{array}$ \\
\hline 2017 & $\begin{array}{c}\text { Sandy } \\
\text { loam }\end{array}$ & 14 & 19 & 67 & 18 & 0.089 & 9.6 & 220 & 0.97 & 0.37 & 1.03 \\
\hline 2018 & $\begin{array}{c}\text { Sandy } \\
\text { loam }\end{array}$ & 16 & 18 & 66 & 21 & 0.093 & 10.1 & 238 & 0.65 & 0.49 & 0.95 \\
\hline
\end{tabular}
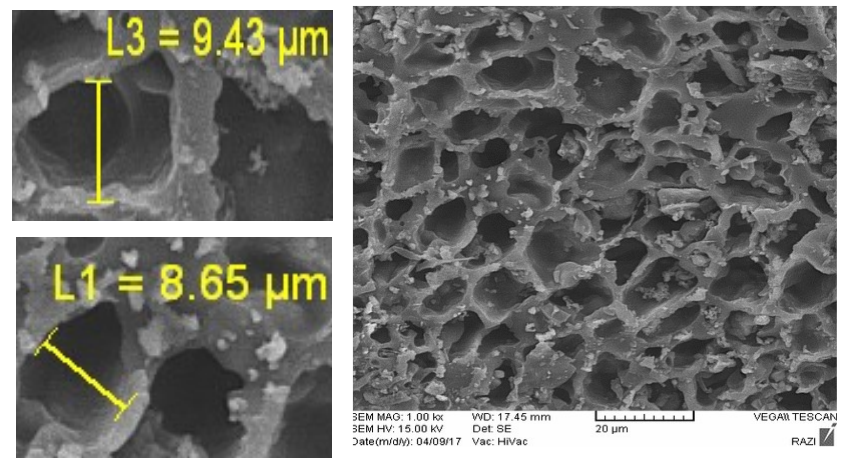

Fig. 2. Scanning Electron Micrograph of biochar. mycorrhiza was also significant on leaf width at the level of $5 \%$ (Table 3 ). In treatments containing 0 and 4 tons biochar per ha, simultaneous application of biochar and mycorrhiza increased leaf width (Fig. 4). The triple interaction effect was also significant on leaf width at the level of $1 \%$ (Table 3 ).

Accordingly, the highest leaf width was related to the level of 8 tons biochar per ha and consumption of mycorrhiza and azotobacter with $19.14 \mathrm{~cm}$. The lowest was related to zero levels of biochar, mycorrhiza and azotobacter with $15.30 \mathrm{~cm}$ (Table 5).

The synergistic effects obtained from the combined use of these factors increase plant growth,

Table 2. Chemical analysis of biochar

\begin{tabular}{|c|c|c|c|c|c|c|c|c|c|}
\hline \multicolumn{10}{|c|}{ Elements weight \% } \\
\hline Silicon & Aluminum & Nitrogen & Iron & Calcium & Potassium & Phosphorous & Magnesium & Oxygen & Carbon \\
\hline 1.43 & 0.19 & 0.31 & 0.43 & 4.27 & 0.38 & 0.18 & 0.0 & 43.71 & 48.83 \\
\hline
\end{tabular}

method (25). The mycorrhizal symbiosis percent was determined by standard method (26).

\section{Nicotine percent}

Nicotine was measured using CORESTA recommended method (27) no. 35 (ISO/DIS 15152).

\section{Statistical analyses}

The effects of treatments were tested via one-way analysis (ANOVA). Duncan's multi-domain test at $\mathrm{P}<0.05$ level was also used to separate the averages of the dependent variables which significantly affected by the treatment. The significant Pearson's correlations between the measured soil and plant parameters were tested. All statistical analyses were carried out using SPSS software (version 24) and Minitab (version 18), graph drawing of Excel software. including leaf length (28). Biofertilizers influence aerial growth, which can be observed in increasing plant height, leaf area and the number of leaves per plant (29). A similar finding was observed by other researchers (30). The multi-microbial biofertilizer was able to increase the height, leaf area and the number of leaves of oil palm plants. The beneficial effect of mycorrhizal and PGPR could be explained by the greater uptake of nutrients. Other studies showed that the application of biofertilizers (AMF and PGPR) improve the $\mathrm{P}$ and $\mathrm{N}$ nutrition and consequently enhances plant growth (31). As per one report it was showed that AMF and PGPR could regulate mineral nutrition by solubilizing nutrients in the soil and producing plant growth regulators (32). Several studies have indicated that AMF and PGPR improve plant growth by assimilating immobile soil nutrients such as $\mathrm{N}$ and $\mathrm{P}$ (33). This resulted from the better 
Table 3. F statistics of combined ANOVA on the different measurements

\begin{tabular}{|c|c|c|c|c|c|c|c|c|c|}
\hline S.O.V & d.f. & $\begin{array}{c}\text { Leaf } \\
\text { length }\end{array}$ & $\begin{array}{c}\text { Leaf } \\
\text { width }\end{array}$ & $\begin{array}{l}\text { Plant } \\
\text { height }\end{array}$ & Dry yield & $\begin{array}{c}\text { Relative } \\
\text { water content }\end{array}$ & $\begin{array}{l}\text { Mycorrhizal } \\
\text { Symbiosis }\end{array}$ & d.f. & Nicotine $\%$ \\
\hline Year & 1 & $1030.95^{* *}$ & $50.7165^{* *}$ & $2529.26^{* *}$ & $3371251^{* *}$ & $374.46^{* *}$ & $70.6^{\mathrm{ns}}$ & 1 & $0.56122 * *$ \\
\hline r(year) & 6 & 13.11 & 1.2310 & 77.02 & 48729 & 1.897 & 28.7 & 4 & 0.00625 \\
\hline B: Biochar & 2 & $208.19^{* *}$ & $26.0416^{* *}$ & $3211.65^{* *}$ & $4903875^{* *}$ & $320.50^{* *}$ & $72.8^{* *}$ & 2 & $0.05070 * *$ \\
\hline $\mathrm{B} \times \mathrm{Y}$ & 2 & $3.77^{\text {ns }}$ & $1.5572^{\text {ns }}$ & $284.70^{\text {ns }}$ & $38244^{\text {ns }}$ & $0.544^{\text {ns }}$ & $9.8^{\mathrm{ns}}$ & 2 & $0.00854^{\mathrm{ns}}$ \\
\hline M: Mycorrhiza & 1 & $3.66^{\mathrm{ns}}$ & $8.1531^{*}$ & $6.57^{\mathrm{ns}}$ & $6189473^{* *}$ & $78.203^{* *}$ & $17888.1^{*}$ & 1 & $0.02809^{\mathrm{ns}}$ \\
\hline A: Azotobacter & 1 & $169.17^{* *}$ & $11.7297^{* *}$ & $1549.98^{* *}$ & $303750 *$ & $1.919^{\mathrm{ns}}$ & $13.8^{\mathrm{ns}}$ & 1 & $2.14102^{* *}$ \\
\hline $\mathrm{A} \times \mathrm{Y}$ & 1 & $0.0001^{\mathrm{ns}}$ & $4.3166^{\mathrm{ns}}$ & $17.05^{\mathrm{ns}}$ & $59203^{\text {ns }}$ & $1.517^{\mathrm{ns}}$ & $11.8^{\mathrm{ns}}$ & 1 & $0.00597^{\text {ns }}$ \\
\hline $\mathrm{B} \times \mathrm{M}$ & 2 & $16.13^{\mathrm{ns}}$ & $4.5081^{*}$ & $86.85^{\mathrm{ns}}$ & $279621 *$ & $12.429^{* *}$ & $78.2 * *$ & 2 & $0.01992^{\text {ns }}$ \\
\hline $\mathrm{B} \times \mathrm{M} \times \mathrm{Y}$ & 2 & $43.06^{* *}$ & $3.9958^{*}$ & $16.94^{\mathrm{ns}}$ & $230508^{\text {ns }}$ & $0.612^{\mathrm{ns}}$ & $10.5^{\mathrm{ns}}$ & 2 & $0.00005^{\text {ns }}$ \\
\hline $\mathrm{B} \times \mathrm{A}$ & 2 & $3.67^{\mathrm{ns}}$ & $0.1275^{\mathrm{ns}}$ & $3.24^{\mathrm{ns}}$ & $29260^{\mathrm{ns}}$ & $16.734^{* *}$ & $1.8^{\mathrm{ns}}$ & 2 & $0.01414^{\text {ns }}$ \\
\hline $\mathrm{B} \times \mathrm{A} \times \mathrm{Y}$ & 2 & $11.87^{\text {ns }}$ & $1.7524^{\mathrm{ns}}$ & $231.74^{\mathrm{ns}}$ & $13742^{\mathrm{ns}}$ & $16.002^{* *}$ & $20.7^{\mathrm{ns}}$ & 2 & $0.00052^{\mathrm{ns}}$ \\
\hline $\mathrm{M} \times \mathrm{A}$ & 1 & $26.15^{*}$ & $3.6206^{\mathrm{ns}}$ & $3.76^{\text {ns }}$ & $9401^{\text {ns }}$ & $36.655^{* *}$ & $9.7^{\text {ns }}$ & 1 & $0.03067^{\text {ns }}$ \\
\hline $\mathrm{M} \times \mathrm{A} \times \mathrm{Y}$ & 1 & $0.36^{\text {ns }}$ & $0.1235^{\mathrm{ns}}$ & $14.73^{\mathrm{ns}}$ & $222915^{\text {ns }}$ & $42.114^{* *}$ & $19.2^{\mathrm{ns}}$ & 1 & $0.00002^{\mathrm{ns}}$ \\
\hline $\mathrm{B} \times \mathrm{M} \times \mathrm{A}$ & 2 & $4.96^{\mathrm{ns}}$ & $8.6901^{* *}$ & $74.64^{\mathrm{ns}}$ & $52152^{\mathrm{ns}}$ & $7.898^{*}$ & $19.9^{\mathrm{ns}}$ & 2 & $0.02618^{*}$ \\
\hline $\mathrm{B} \times \mathrm{M} \times \mathrm{A} \times \mathrm{Y}$ & 2 & $4.13^{\mathrm{ns}}$ & $0.7252^{\mathrm{ns}}$ & $162.63^{\mathrm{ns}}$ & $62279^{\text {ns }}$ & $6.284^{*}$ & $16.3^{\mathrm{ns}}$ & 2 & $0.00007^{\text {ns }}$ \\
\hline Error & 66 & 6.04 & 1.1953 & 98.92 & 76744 & 1.833 & 11.6 & 44 & 0.00709 \\
\hline C.V. (\%) & - & 9.4 & 6.1 & 13.1 & 10.5 & 1.8 & 4.71 & - & 4.3 \\
\hline
\end{tabular}

Significant at the 0.05 and 0.01 probability levels, respectively and ns: Non- significant * and ${ }^{* *}$

Table 4. Main effect of year, biochar, mycorrhiza and azotobacter on the different measurements.

\begin{tabular}{|c|c|c|c|c|c|c|c|c|}
\hline & & $\begin{array}{l}\text { Leaf length } \\
\text { (cm) }\end{array}$ & $\begin{array}{l}\text { Leaf width } \\
\text { (cm) }\end{array}$ & $\begin{array}{l}\text { Plant height } \\
\text { (cm) }\end{array}$ & $\begin{array}{l}\text { Dry yield } \\
\text { (kg/ha) }\end{array}$ & $\begin{array}{c}\text { Relative water } \\
\text { content }(\%)\end{array}$ & $\begin{array}{c}\text { Mycorrhizal } \\
\text { Symbiosis (\%) }\end{array}$ & Nicotine \% \\
\hline \multirow{2}{*}{ Year } & 2017 & $32.13 \mathrm{~b}$ & $17.05 \mathrm{~b}$ & $81.15 \mathrm{a}$ & $2455 \mathrm{~b}$ & $75.1 \mathrm{~b}$ & $17.8 \mathrm{~b}$ & $1.86 \mathrm{~b}$ \\
\hline & 2018 & $38.68 \mathrm{a}$ & $18.51 \mathrm{a}$ & $70.89 \mathrm{~b}$ & $2798 \mathrm{a}$ & $79.1 \mathrm{a}$ & $19.5 \mathrm{a}$ & $2.04 \mathrm{a}$ \\
\hline \multirow{3}{*}{ Biochar } & B0 & $32.69 \mathrm{c}$ & $16.87 \mathrm{c}$ & $65.09 \mathrm{c}$ & $2228 \mathrm{~b}$ & $73.5 \mathrm{c}$ & $16.9 \mathrm{~b}$ & $1.91 \mathrm{~b}$ \\
\hline & B4 & $35.77 \mathrm{~b}$ & $17.79 \mathrm{~b}$ & $78.21 \mathrm{~b}$ & $2723 a$ & $78.2 \mathrm{~b}$ & $19.8 \mathrm{a}$ & $1.97 \mathrm{a}$ \\
\hline & B8 & $37.75 \mathrm{a}$ & $18.68 \mathrm{a}$ & $84.76 \mathrm{a}$ & $2928 \mathrm{a}$ & $79.5 \mathrm{a}$ & $19.3 \mathrm{a}$ & $2.00 \mathrm{a}$ \\
\hline \multirow{2}{*}{ Mycorrhiza } & M0 & $35.21 \mathrm{a}$ & $17.49 \mathrm{~b}$ & $76.28 \mathrm{a}$ & $2365 \mathrm{~b}$ & $76.2 \mathrm{~b}$ & $5.0 \mathrm{~b}$ & $1.93 \mathrm{a}$ \\
\hline & M1 & $35.60 \mathrm{a}$ & $18.07 \mathrm{a}$ & $75.76 \mathrm{a}$ & $2887 \mathrm{a}$ & $78.0 \mathrm{a}$ & $32.3 \mathrm{a}$ & $1.97 \mathrm{a}$ \\
\hline \multirow{2}{*}{ Azotobacter } & $\mathrm{A} 0$ & $34.07 \mathrm{~b}$ & $17.43 \mathrm{~b}$ & $72.00 \mathrm{~b}$ & $2581 \mathrm{~b}$ & $76.9 \mathrm{a}$ & $18.3 \mathrm{a}$ & $1.77 \mathrm{~b}$ \\
\hline & A1 & $36.73 \mathrm{a}$ & $18.13 \mathrm{a}$ & $80.04 \mathrm{a}$ & $2671 \mathrm{a}$ & $77.2 \mathrm{a}$ & $19.0 \mathrm{a}$ & $2.12 \mathrm{a}$ \\
\hline
\end{tabular}

Means with a common letter in the same column do not differ significantly at $\mathrm{P}<0.05$

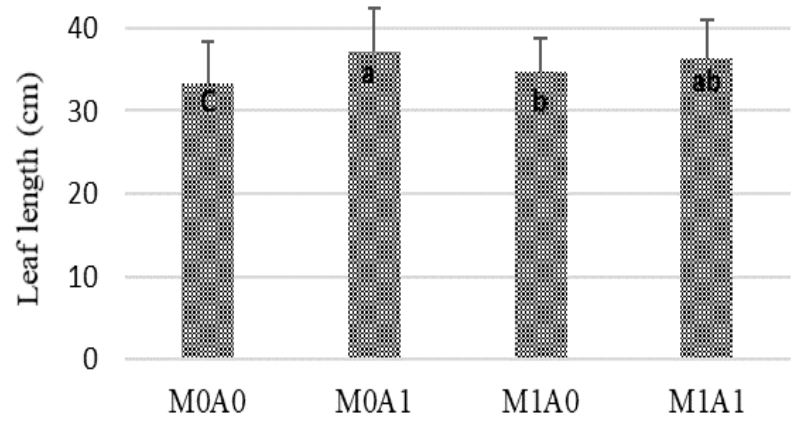

Fig. 3. Effect of mycorrhiza and azotobacter on leaf length. M0: no mycorrhiza application, M1: mycorrhiza application, A0: no azotobacter application and A1: azotobacter application.

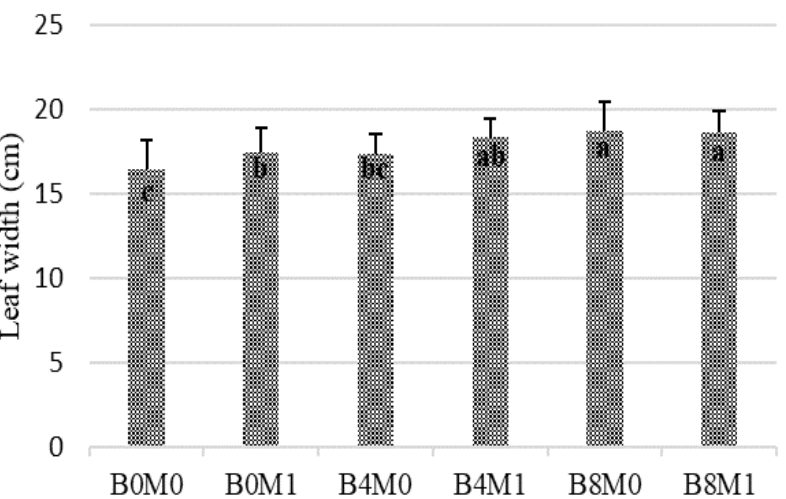

Fig. 4. Effect of biochar and mycorrhiza on leaf width. B0: no biochar application, B4: application 4 ton/ha of biochar, B8: application 8 ton/ha of biochar, M0: no mycorrhiza application and M1: mycorrhiza application. absorption of the surface area provided by extensive fungal hyphae to plant root (34) or the mobilization and absorption of various nutrients from the soil to plants by PGPR (35).

\section{Dry yield}

The results showed that in the second year, dry leaf yield was $14 \%$ higher than in the first year (Table 4 ).
Tobacco yield was significantly $(\mathrm{p}<0.01)$ affected by biochar, mycorrhiza and azotobacter application (Table 3). With increasing the level of biochar added, leaf yield also increased (Table 4). Although biochar had a gradual promoting effect on tobacco yield however no significant difference was observed among 4 and 8 ton/ha levels (Table 4). In the meantime, tobacco yield enhanced continually by 
Table 5. Triple interaction of biochar, mycorrhiza and azotobacter on some measurements

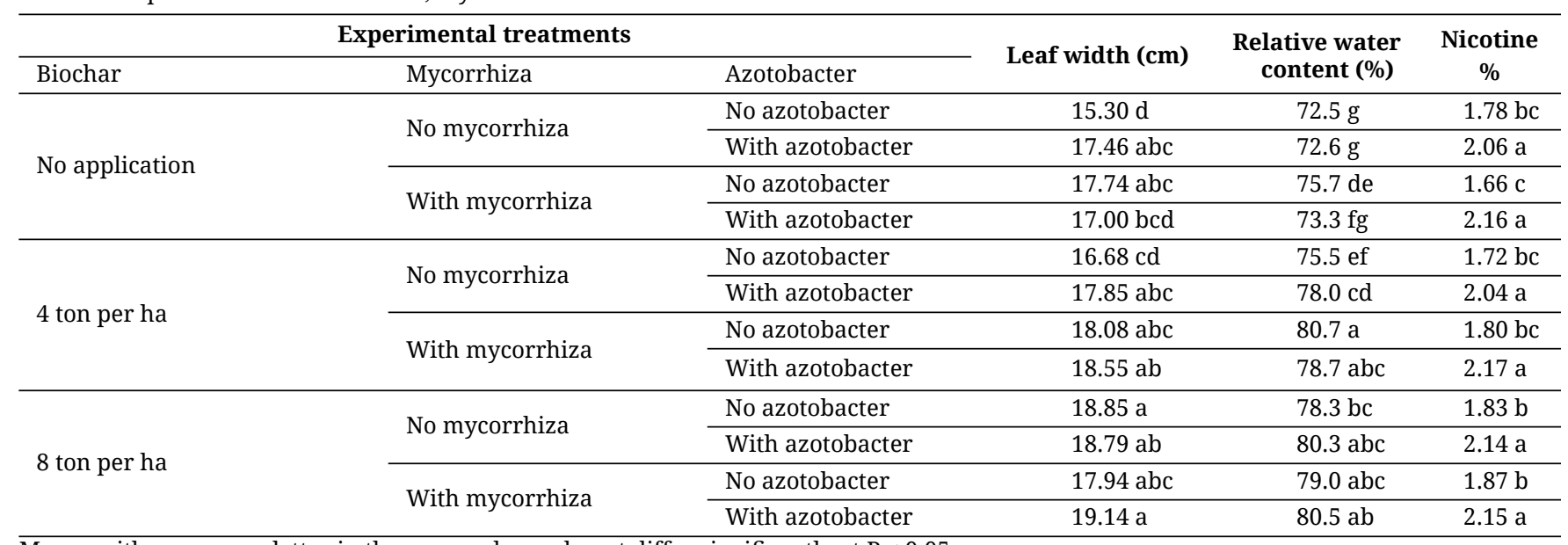

Means with a common letter in the same column do not differ significantly at $\mathrm{P}<0.05$

increasing biochar and application dosage 4 and 8 ton/ha in the soil caused 22 and $31 \%$ increase compared to no biochar application respectively (Table 4). Application of mycorrhiza compared with absence improved dry yield significantly by about 22 $\%$. The same trend was observed with azotobacter (Table 4). Simultaneous applied of biochar and mycorrhizal had a significant effect $(p<0.05)$ on dry yield (Table 3 ). The maximum yield of the dry leaf (3273 kg/ha) was obtained with the highest level of biochar and mycorrhiza application. However, the increase in biochar applied from 4 to 8 ton/ha in treatments containing mycorrhiza improved only dry yield 7\% (Fig. 5).

In this study, rainfall rate and distribution during the tobacco cultivation season were more appropriate, with only one case of $40 \mathrm{~mm}$ of rainfall before the beginning of the flowering stage, causing proper growth and development of tobacco plants (Fig. 1).

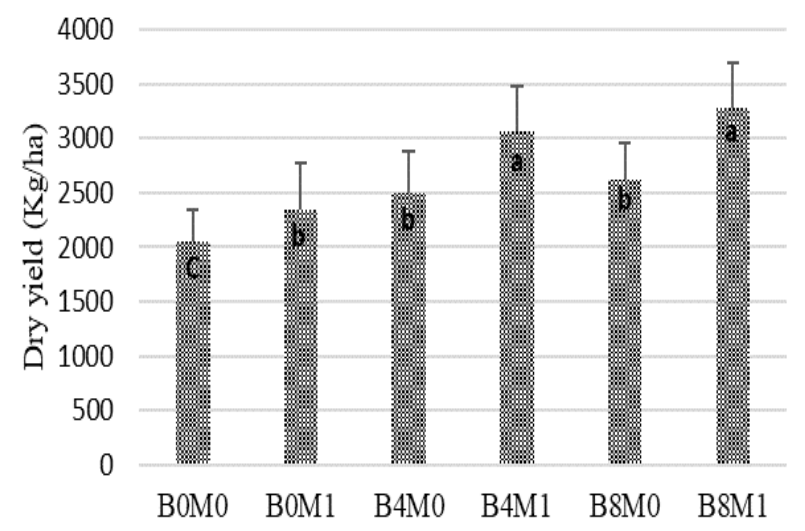

Fig. 5. Effect of biochar and mycorrhiza on dry yield. B0: no biochar application, B4: application 4 ton/ha of biochar, B8: application 8 ton/ha of biochar, M0: no mycorrhiza application and M1: mycorrhiza application.

Biochar application promoted the growth and development of aboveground organs of tobacco. The presence of nutrients in the biochar structure and its large surface area, porous nature and the ability to act as a shelter for microorganisms have been identified as the main reasons for increased plant yield (36). It has been reported that the biochar can reduce the risk of soil compaction (37) and mixing with the plant growth-promoting microorganisms was referred to as the best combination for growth and yield of French beans (38). The addition of biochar in the soil can be beneficial to improve the soil quality, as well as to stimulate plant growth and can play an important role in developing a sustainable system of agriculture. Biochar has the potential to improve soil properties, microbial abundance, biological nitrogen fixation and plant growth. Several uses and positive effects of biochar amendment have currently been considered as an effective method to achieve high crop yields without harming the natural environment (39). The use of biochar increases plant growth, biomass and absorption of nutrients in water deficit conditions (40, 41). These effects can be attributed to the $K$ and $P$ sources in biochar, which can be released through further mineralization in the soil. Our findings emphasized that biochar application increase macroelements content in plants and soil. It has also been announced that the improved yield in crops with biochar application is due mainly to conserving the water in its porosity (42). Several previous studies have shown that mycorrhiza and plant growthpromoting bacteria can reduce the effects of water deficit stress in many plants (43). Symbiotic microorganisms, especially AM fungi, reduce the effects of water deficit stress by raising the water and nutrient content in plant tissues (44). In this study, the azotobacter application increased tobacco yield but not sufficiently. The stimulant effect of Azotobacter chroococcum, including various mechanisms such as the production of siderophore and nitrogen, stimulates plant growth and increases yield (45).

\section{Relative water content}

The results showed that a significant effect $(\mathrm{p}<0.01)$ of the year on relative water content (Table 3 ). Relative water content was significantly $(p<0.01)$ affected by biochar application (Table 3). In treatments containing biochar, the average relative leaf water content was $80 \%$, while the RWC level in treatments without biochar was $73.5 \%$ (Table 4). It has been reported that biochar mixing with soil can affect soil physical properties such as structure, pore distribution and density, aeration, water holding capacity and plant growth (46). The effect of biochar on increasing the soil water holding capacity may be due to the increase in the specific surface of the soils (47). The effect of 
mycorrhiza application was also statistically significant on the relative water content (Table 3). The interaction between biochar $\times$ mycorrhiza was significant at the level of $5 \%$ (Table 3 ). With the increasing application of biochar and mycorrhiza, the relative water content also increased (Fig. 6).

It has been reported that under water stress conditions, mycorrhizal symbiosis had positive effects on the plant water status (48). Preserving higher RWC in mycorrhizal plants suggests a tolerance strategy by

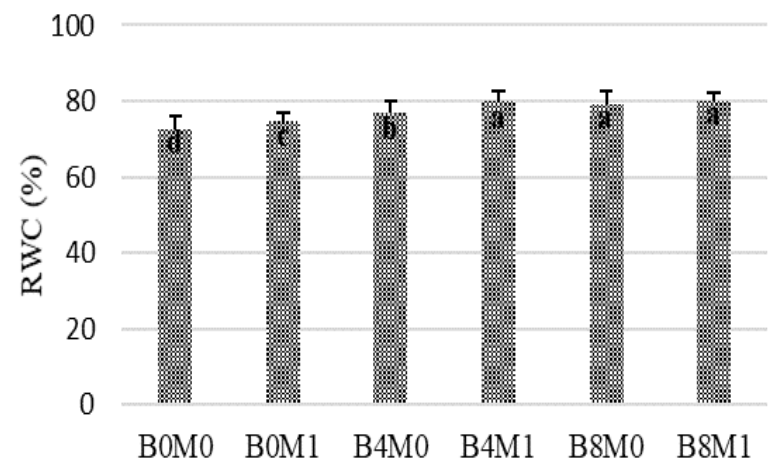

Fig. 6. Effect of biochar and mycorrhiza on relative water content. B0: no biochar application, B4: application 4 ton/ha of biochar, B8: application 8 ton/ha of biochar, M0: no mycorrhiza application and M1: mycorrhiza application.

reducing the water loss and making the water stress pressure on the plant evade. The ability of the mycorrhizal root to improve water absorption under lower soil water potential contributed in maintaining RWC under drought stress (49).

In this experiment, although azotobacter had a gradual promoting effect on the relative water content but this effect was not significant. Azotobacter chroococcum have been highlighted as the most important live nitrogen fixing bacteria and potential bacterial biological fertilizer with proven effects such as improving plant nutrition and soil biological fertility, protection against pathogens and phytohormone biosynthesis (50). The interaction effect of biochar $\times$ azotobacter also had a significant effect on the relative water content at the level of $1 \%$ (Table 3). The combination of 4 or 8 ton/ha biochar with azotobacter increased the relative water content (Fig. 7).

The interaction effect of mycorrhiza $x$ azotobacter was also significant at $1 \%$ (Table 3 ). The lowest relative water content was obtained at the zero levels of mycorrhiza and azotobacter (Fig. 8).

The interaction of the three experimental factors was also significant at 1\% (Table 3). The water holding capacity of most soils under stress conditions is due to the high adsorption capacity and porous structure of the biochar (51).

\section{Mycorrhizal symbiosis}

The mycorrhizal inoculum significantly $(p<0.01)$ increased the extent of the root symbiosis compared to the non-inoculated treatments (Table 3). In this regard, the application of mycorrhiza significantly enhanced the average symbiosis rate from 5\% to $32 \%$ (Table 4). Symbiosis rate was positively affected and increased significantly $(\mathrm{p}<0.01)$ by biochar application

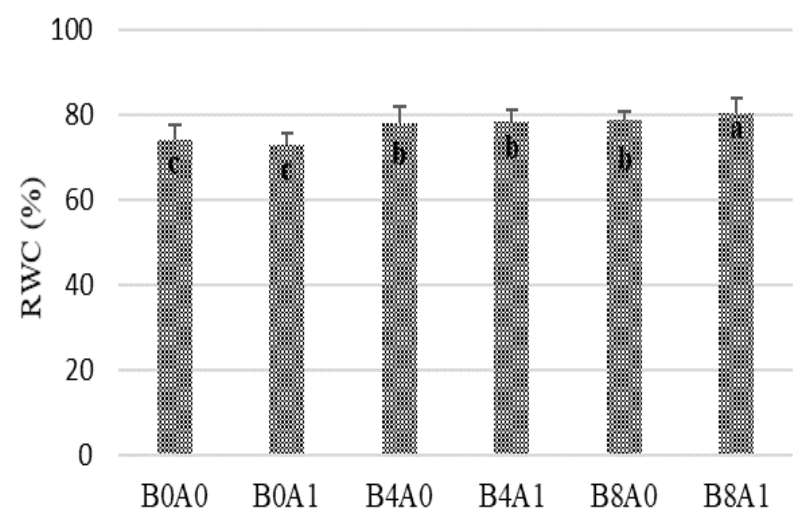

Fig. 7. Effect of biochar and azotobacter on relative water content. B0: no biochar application, B4: application 4 ton/ha of biochar, B8: application 8 ton/ha of biochar, A0: no azotobacter application and A1: azotobacter application.

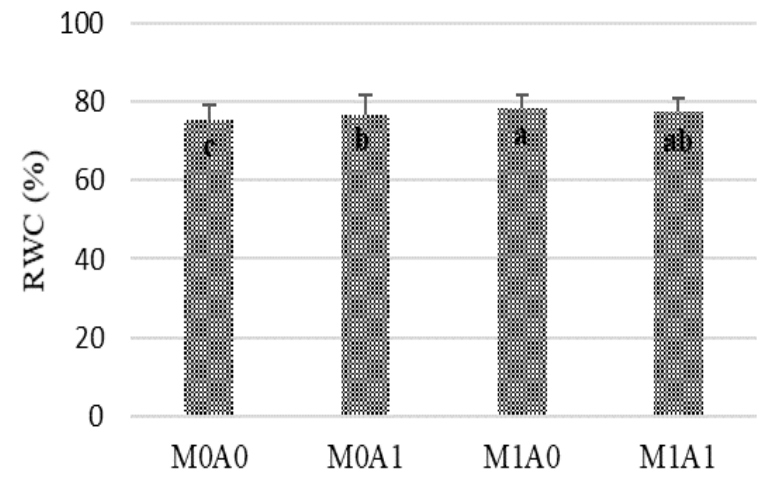

Fig. 8. Effect of mycorrhiza and azotobacter on relative water content. M0: no mycorrhiza application, M1: mycorrhiza application, A0: no azotobacter application and A1: azotobacter application.

(Table 3) but not strong enough, varying from 17 to $20 \%$ (Table 4). Still, there were not any significant effects by azotobacter application (Table 3). It has already resulted that the biochar amendment can act as contributory, which improves the possibility of mycorrhiza to colonize roots. Mycorrhizal fungi symbiosis by plant roots was reported from very distant years (52). This type of communication, known as the sequence of biological functions, has positive and beneficial effects on natural and agroecosystems (53, 54). Simultaneous application of biochar with mycorrhiza caused approximately increases in root symbiosis from 5\% to $34 \%$ compared to untreated control (without biochar and mycorrhiza application) (Fig. 9).

Biochar changes the ability of the soil nutrients to access, plays a role in altering the activity of other microorganisms, detoxifies harmful chemicals in the soil or changes the signaling processes between the plant and the fungus (55). The increasing effect of biochar in root symbiosis is related to the growth improvement of fungal hyphae under water deficit conditions (15). The indirect effect of biochar on increasing fungal propagation in roots and soil may be due to the cumulative effect on root growth (56). Biochar can attract mycorrhizal fungus through mineral nutrients on its surface or by playing as a 


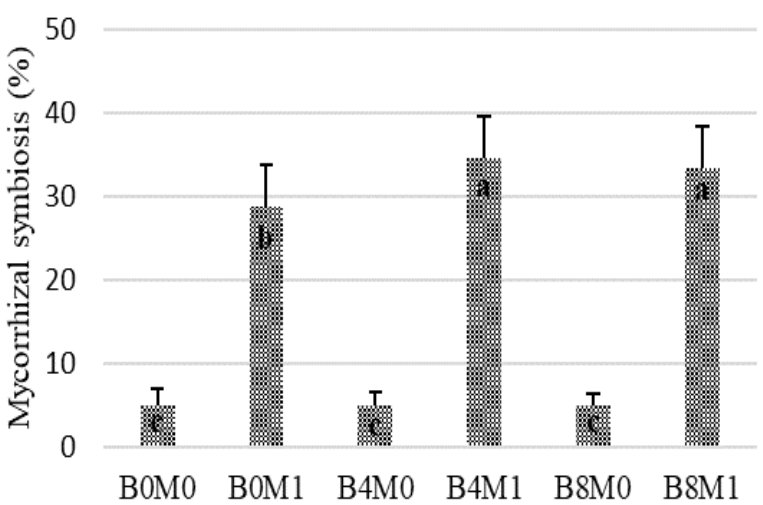

Fig. 9. Effect of biochar and mycorrhiza on mycorrhizal symbiosis. B0: no biochar application, B4: application 4 ton/ha of biochar, B8: application 8 ton/ha of biochar, M0: no mycorrhiza application and M1: mycorrhiza application.

shelter (57). Further researches are needed to elucidate issues included the biochar particle size effect, the reaction of biochar with other species of mycorrhiza and the soil characteristics.

\section{Nicotine \%}

In this experiment, the average percentage of nicotine in the first year was 1.86, which was enhanced by approximately $10 \%$ in the second year to $2.04 \%$ (Table 4). The biochar application had a significant effect on nicotine content $(\mathrm{P}<0.01)$, varying from 1.91 to $2.0 \%$ (Table 4). No significant difference was observed between 4 and $8 \mathrm{~kg} / \mathrm{ha}$ of biochar, which showed a positive effect on nicotine. No more increment would be observed in higher amounts in rainfed conditions. Azotobacter had a significant influence on nicotine content (Table 3) which had the most significant effect with $20 \%$ on nicotine content (Table 4). Only the triple effect of experimental factors was significant on nicotine content at $5 \%$ (Table 3), which varied between 1.65 and $2.16 \%$ (Table 5). The chemical composition of tobacco leaves determines their quality. The most valuable quality assessment criterion in tobacco is nicotine content (58), used in the pharmaceutical industry and agricultural pesticides (59). In the tobacco plant, the root is the site of nicotine synthesis and transfer to the aerial organs, especially to the leaves (58). The tobacco leaf nicotine content is strongly dependent on soil conditions. This alkaloid is affected by the soil nitrogen content provided by biofertilizers. The results showed that azotobacter had a decisive role in leaf nicotine content. In this study, an increase in nicotine was recorded using azotobacter as a fixer of atmospheric nitrogen, which is present in the molecular structure of nicotine (60). This could be why the positive effects of azotobacter on tobacco leaves $\mathrm{N}$ content were related to the highest increases in nicotine. Azotobacter alone induced more positive and more decisive effects on tobacco leaf nicotine content. The results of a study showed that nicotine levels increased in treatments containing $A$. chroococcum (21). Results showed a positive and significant effect of biochar on nicotine content. Although mycorrhizal symbiosis enhances mineral uptake by plant roots (61) and further by-products of the plants, there was not any significant effect of mycorrhizal fungi on nicotine.

\section{Conclusion}

Currently, the use of harmless sources such as biofertilizers and compounds such as biochar is one of the known solutions to reduce the consumption of agrochemical inputs. This study showed that using biochar with a positive and significant effect on morpho-physiological traits improves yield in tobacco. Also, it was proved that the biofertilizers included mycorrhiza and azotobacter improved the growth performance in tobacco under rainfed conditions, such as dry leaf yield. No significant difference was observed between the levels of 4 and 8 tons/ha of biochar on some evaluated traits as dry leaf yield and nicotine content. Therefore, in terms of economic factors, 4 tons per ha of biochar is recommended. Furthermore, the role of mycorrhizal fungi and Azotobacter chroococcum in improving the quantitative and qualitative indicators of tobacco was positive and significant for most of the evaluated traits. The use of azotobacter to increase the nicotine content of tobacco leaves can be considered a practical solution in rainfed tobacco areas.

\section{Acknowledgements}

The authors would like to acknowledge all technicians who actively supported the field and lab works during the two years of this experiment.

\section{Authors' contributions}

RM Collected the data (field and lab works), data analysis, writing the article. MRA performed the research concept and design, field works, writing the article, critical revision of the article and final approval of the article. AM contributed to the research conception and design, statistical analysis and writing the article. FR contributed to research conception and design and lab work.

\section{Compliance with ethical standards}

Conflict of interest: The authors declare that they have no competing interests.

Ethical issues: None.

\section{References}

1. Ganapathi TR, Suprasanna P, Roa PS, Bapat VA. Tobacco (Nicotiana tabacum L.) Amodel system for tissue culture interventions and genetic engineering. Indian Journal of Biotechnology. 2004;3:171-84.

2. Tang Z, Chen L, Chen Z, Fu Y, Sun X et al. Climatic factors determine the yield and quality of Honghe flue-cured tobacco. Scientific Reports. 2020;10, Article number: 19868 https://doi.org/10.1038/s41598-020-76919-0

3. Soliman MH, Abdulmajeed AM, Alhaithloul H, Alharabi BM, ElEsawi MA, Hasanuzzaman M, Elkelish A. Saponin biopriming positively stimulates antioxidants defense, osmolytes metabolism and ionic status to confer salt stress tolerance in soybean. Acta Physiologiae Plantarum. 2020;42:114. https://doi.org/10.1007/s11738-020-03098-w

4. Major J, Rondon M, Molina D, Riha SJ, Lehmann J. Maize yield and nutrition during 4 years after biochar application to a Colombian savanna oxisol. Plant and Soil. 2010;333:117-28. https://doi.org/10.1007/s11104-010-0327-0

5. El Nahhas N, AlKahtani MDF, Abdelaal KAA, Al Husnain L, AlGwaiz HIM, Hafez YM, Attia KA, El-Esawi MA, Ibrahim MFM, Elkelish A. Biochar and jasmonic acid application attenuates 
antioxidative aystems and improves growth, physiology, nutrient uptake and productivity of Faba bean (Vicia faba L.) irrigated with saline water. Plant Physiology and Biochemistry. 2021;166:807-17. https://doi.org/10.1016/j.plaphy.2021.06.033

6. Abbas T, Rizwan M, Ali S, Zia-ur-Rehman M, Qayyam MF, Abbas F, Hannan F, Rinklebe J, Ok YS. Effect of biochar on cadmium bioavailability and uptake in wheat (Triticum aestivum L.) grown in a soil with aged contamination. Ecotoxicology and Environmental Safety. https://doi.org/10.1016/j.ecoenv.2017.02.028

7. Mousavi SA, Shokuhfar A, Lak S, Mojaddam M, Alavifazel M. Integrated application of biochar and bio-fertilizer improves yield and yield components of cowpea under water-deficient stress. Italian Journal of Agronomy. 2020;15:94-101. https://doi.org/10.4081/ija.2020.1581

8. Jaafar NM, Clode PL, Abbott LK. Soil microbial responses to biochars varying in particle size, surface and pore properties. Pedosphere. 2015;25:770-80. https://doi.org/10.1016/S10020160(15)30058-8

9. Kim HS, Kim KR, Yang JE, Ok YS, Owens G, Nehls T, Wessolek G, $\mathrm{Kim} \mathrm{KH}$. Effect of biochar on reclaimed tidal land soil properties and maize (Zea mays L.) response. Chemosphere. 2016;142:15359. https://doi.org/10.1016/j.chemosphere.2015.06.041

10. Lim TJ, Spokas KA, Feyereisen G, Novak JM. Predicting the impact of biochar additions on soil hydraulic properties. Chemosphere. https://doi.org/10.1016/j.chemosphere.2015.06.069

11. Ojeda G, Mattana $S$, Àvila $A$, Alcaniz JM, Volkmann $M$ Bachmann J. Are soil-water functions affected by biochar application? Geoderma. 2015;249:1-11. https://doi.org/10.1016/j.geoderma.2015.02.014

12. Jiangzhou L, Sigui J, Limeng Z, Qingzhong Z. Effects of biochar on soil quality and tobacco growth during four years of consecutive application. Institute of Environmental and Sustainable Development in Agriculture. Chinese Agricultural Science. 2016; APPOST 16.

13. Shokri S, Maadi B. Effects of arbuscular mycorrhizal fungus on the mineral nutrition and yield of Trifolium alexandrinum plants under salinity stress. Journal of Agronomy. 2009;8:79-83. https://doi.org/10.3923/ja.2009.79.83

14. Roesti D, Gaur R, Johri B, Imfeld G, Sharma S, Kawalijeet K, Aragno M. Plant growth stage, fertilizer management and bioinoculation of arbuscular mycorrhizal fungi and plant growth promoting rhizobacteria affect the rhizobacterial community structure in rain-fed wheat fields. Soil Biology and Biochemistry. https://doi.org/10.1016/j.soilbio.2005.09.010

15. Mickan BS, Abbott LK, Stefanova K, Solaiman ZM. Interactions between biochar and mycorrhizal fungi in a water-stressed agricultural soil. Mycorrhiza. 2016;26:565-74. https://10.1007/s00572-016-0693-4

16. Aquilanti L, Favilli F, Clementi F. Comparison of different strategies for isolation and preliminary identification of azotobacter from soil samples. Soil Biology and biochemistry. 2004;36(9):1475-83. https://doi.org/10.1016/j.soilbio.2004.04.024

17. Sandhya V, Ali SKZ, Grover M, Reddy G, Enkateswarlu BV. Effect of plant growth promoting Pseudomonas spp. on compatible solutes, antioxidant status and plant growth of maize under drought stress. Plant Growth Regulation. 2010;62:21-30. https://doi.org/10.1007/s10725-010-9479-4

18. Shabani G, Ardakani MR, Chaichi MR, Friedel JK, Khavazi K Effect of different fertilizing treatments on nutrient uptake in annual medic (Medicago scutellata cv. robinson) under irrigated and dry farming systems. Journal of agricultural science and technology. 2015;17:299-310. http://jast.modares.ac.ir/article-2310126-en.html

19. Abbasi MK, Sharif S, Kazmi M, Sultan T, Aslam M. Isolation of plant growth promoting rhizobacteria from wheat rhizosphere and their effect on improving growth, yield and nutrient uptake of plants. Plant Biosystems. 2011;145(1):159-68. https://doi.org/10.1080/11263504.2010.542318

20. Zaidi A, Khan MS, M Ahemad M, Oves M. Plant growth promotion by phosphate solubilizing bacteria. Acta Microbiologica et Immunologica Hungarica. 2009;56(3):263-84. https://doi.org/10.1556/AMicr.56.2009.3.6

21. Subhashini DV. Effect of bio-inoculation of AM fungi and PGPR on the growth, yield and quality of FCV tobacco (Nicotiana tabacum) in vertisols. Indian Journal of Agriculture Science. 2013;83(6):667-72.
22. Ruscitti M, Arango M, Ronco M, Beltrano J. Inoculation with mycorrhizal fungi modifies proline metabolism and increases chromium tolerance in pepper plants (Capsicum annuum L.). Brazilian society of plant physiology. 2011;23(1):15-25.

23. Jnawali AD, Ojha RB, Marahatta S. Role of azotobacter in soil fertility and sustainability-a review. Advances in Plants and Agriculture Research. https://doi.org/10.15406/apar.2015.02.00069

24. Smart RE, Bingham GE. Rapid estimates of relative water $\begin{array}{lll}\text { content. } & \text { Plant } & \text { Physiology. }\end{array}$ https://doi.org/10.1104/pp.53.2.258

25. Phillips JM, Hayman DS. Improved procedures for clearing roots and staining parasitic and vesicular arbuscular mycorrhizal fungi for rapid assessment of infection. Transactions of the British Mycological Society. 1970;55:158-61.

26. Giovannetti M, Mosse B. An evaluation of techniques for measuring vesicular arbuscular mycorrhizal infection in roots. New Phytologist. 1980;84(3):489-500. https://doi:10.1111/j.14698137.1980.tb04556.x

27. CORESTA recommended method No 35. Determination of total alkaloids (as nicotine) in tobacco by continuous flow analysis. 1994; Available from: https://www.coresta.org/sites/default/files/technical_documents/ main/CRM_35-updateAug10.pdf

28. Copetta A, Lingua G, Berta G. Effects of three AM fungi on growth, distribution of glandular hairs and essential oil production in Ocimum basilicum L. Mycorrhiza. 2006;16:485-94. https://doi.org/10.1007/s00572-006-0065-6

29. Park, Y-S, Park K, Kloepper JW, Ryu C-M. Plant GrowthPromoting Rhizobacteria stimulate vegetative growth and asexual reproduction of Kalanchoe daigremontiana. The Plant Pathology Journal. 2015;31:310-15. https://doi.org/10.5423/PPJ.NT.01.2015.0006

30. Adiprasetyo T, Purnomo B, Handajaningsih M, Hidayat H. The usage of BIOM3G-Biofertilizer to improve and support sustainability of land system of independent oil palm smallholders. International Journal of Advance Science. 2014;4:345-48. http://dx.doi.org/10.18517/ijaseit.4.5.431

31. Javan Gholiloo M, Yarnia M, Ghorttapeh AH, Farahvash F, Daneshian AM. Evaluating effects of drought stress and biofertilizer on quantitative and qualitative traits of valerian (Valeriana officinalis L.). Journal of Plant Nutrition. 2019;42:1417-29. https://doi.org/10.1080/01904167.2019.1628972

32. Nadeem SM, Ahmad M, Zahir ZA, Javaid A, Ashraf M. The role of mycorrhizae and plant growth promoting rhizobacteria (PGPR) in improving crop productivity under stressful environments. Biotechnology Advances. 2014;32:429-448. https://doi.org/10.1016/j.biotechadv.2013.12.005

33. Raklami A, Bechtaoui N, Tahiri A, Anli M, Meddich A, Oufdou K. Use of rhizobacteria and mycorrhizae consortium in the open field as a strategy for improving crop nutrition, productivity and soil fertility. Frontiers in Microbiology. 2019;10:1106. https://doi.org/10.3389/fmicb.2019.01106

34. Yu YY, Li SM, Qiu JP, Li JG, Luo YM, Guo JH. Combination of agricultural waste compost and biofertilizer improves yield and enhances the sustainability of a pepper field. Journal of Plant Nutrition and Soil Science. 2019;182:560-569. https://doi.org/10.1002/jpln.201800223

35. Grobelak A, Napora A, Kacprzak M. Using plant growthpromoting rhizobacteria (PGPR) to improve plant growth Ecological Engineering. 2015;84:22-28. https://doi.org/10. 1016/j.ecoleng.2015.07.019

36. Nigussie A, Kissi E, Misganaw M, Ambaw G. Effect of biochar application on soil properties and nutrient uptake of Lettuces (Lactuca sativa) grown in chromium polluted soils. AmericanEurasian Journal of Agriculture and Environmental Science. 2012;12(3):369-376.

37. Chan K, Van Zwieten L, Meszaros I, Downie A, Joseph S. Using poultry litter biochars as soil amendments. Australian Journal of Soil Research. 2008;46(5):437-444.

38. Saxena J, Rana G, Pandey M. Impact of addition of biochar along with Bacillus sp. on growth and yield of French beans. Scientia Horticulturae. https://doi.org/10.1016/J.SCIENTA.2013.08.002

39. Placek A, Grobelak A, Kacprzak M. Improving the phytoremediation of heavy metals contaminated soil by use of sewage sludge. International Journal of Phytoremediation. 2016;18(6):605-18.

https://doi.org/10.1080/15226514.2015.1086308 
40. Agegnehu G, Srivastava A, Bird MI. The role of biochar and biochar-compost in improving soil quality and crop performance: a review. Applied Soil Ecology. 2017;119:156-70. https://doi.org/10.1016/j.apsoil.2017.06.008

41. Suliman W, Harsh JB, Abu-Lail NI, Fortun AM, Dallmeyer I, GarciaPérez M. The role of biochar porosity and surface functionality in augmenting hydrologic properties of a sandy soil. Science of Total Environment. 2017;574:139-47. https://doi.org/10.1016/j.scitotenv.2016.09.025

42. Tayyab M, Islam W, Khalil F, Ziqin P, Caifang Z, Arafat Y, Hui L, Rizwan M, Ahmad K, Wahhed S, Tarin MWK, Hua Z. Biochar: an efficient way to manage low water availability in plants. Applied Ecology and Environmental Research. 2018;16:2565-83 https:// 10.15666/aeer/1603_25652583

43. Behrooz A, Vahdati K. Arbuscular mycorrhiza and plant growthpromoting bacteria alleviate drought stress in Walnut. American Society for Horticultural Science. 2019;54:1087-1092. https://doi.org/10.21273/HORTSCI13961-19

44. Rapparini F, Penuelas J. Mycorrhizal fungi to alleviate drought stress on plant growth, In: M. Miransari (ed.). Use of microbes for the alleviation of soil stresses. Vol. 1. Springer, New York, NY. 2014;1:21-42. https://10.1007/978-1-4614-9466-9_2

45. Castiglione AM, Mannino G, Contartese V, Bertea CM, Ertani, A. Microbial biostimulants as response to modern agriculture needs: composition, role and application of these innovative products. Plants. 2021;10: 1533. https://doi.org/10.3390/ plants10081533

46. Downie A, Crosky A, Munroe P. Physical properties of biochar In: J. Lehmann and S. Joseph (Eds.). Biochar for Environmental Management: Science and Technology. $3^{\text {rd }}$ Ed, London, Earthscan; 2009. 405 p.

47. Glaser B, Lehmann J, Zech W. Ameliorating physical and chemical properties of highly weathered soils in the tropics with charcoal a review. Biology and Fertility of Soils. 2002;35(4):219230. https://doi.org/10.1007/s00374-002-0466-4

48. Beltrano J Ronco MG. Improved tolerance of wheat plants (Triticum aestivum L.) to drought stress and rewatering by the arbuscular mycorrhizal fungus Glomus claroideum: effect on growth and cell Membrane stability, Brazilian Journal of Plant Physiology. 2008;20:29-37. https://doi.org/10.1590/S167704202008000100004

49. Meddich A, Oihabi A, Abbas Y, Essia B. Rôle des champignons mycorhiziens à arbuscules de zones arides dans la résistance du trèfle (Trifolium alexandrinum L.) au déficit hydrique au deficit hydrique, Agronomie. https://doi.org/10.1051/agro:2000127

50. Aasfar A, Bargaz A, Yaakoubi K, Abderraouf Hilali A, Bennis I, Zeroual Y, Kadmiri IM. Nitrogen fixing azotobacter species as potential soil biological enhancers for crop nutrition and yield $\begin{array}{llll}\text { stability. 2021; } & \text { Front. Microbiol. 12:628379. }\end{array}$ https://doi.org/10.3389/fmicb.2021.628379

51. Lawlor DW, Cornic G. Photosynthetic carbon assimilation and associated metabolism in relation to water deficits in higher plants. Plant, Cell and Environment. 2002;25(2):275-94. https://doi.org/10.1046/j.0016-8025.2001.00814.x

52. Selosse MA, Strullu-Derrien C, Martin FM, Kamoun S, Kenrick P. Plants, fungi and oomycetes: a 400-million years' affair that shapes the biosphere. New Phytologist. 2015;206:501-06. https://doi.org/10.1111/nph.13371
53. Davaran Hagh E, Mirshekari B, Ardakani MR, Farahvash F, Rejali F. Optimizing phosphorus use in sustainable maize cropping via mycorrhizal inoculation. Journal of Plant Nutrition.

https://doi.org/10.1080/01904167.2015.1086797

54. Van der Heijden MG, Martin FM, Selosse MA, Sanders IR. Mycorrhizal ecology and evolution: the past, the present and the $\begin{array}{lll}\text { future. New Phytologist. 2015;205:1406-1423. } & \text {. }\end{array}$ https://doi.org/10.1111/nph.13288

55. Warnock DD, Lehmann J, Kuyper TW, Rillig MC. Mycorrhizal responses to biochar in soil concepts and mechanisms. Plant and Soil. 2007;300:9-20. https://doi.org/10.1007/s11104-007-93915

56. Hammer EC, Forstreuter M, Rillig MC, Kohler J. Biochar increases arbuscular mycorrhizal plant growth enhancement and ameliorates salinity stress. Applied Soil Ecology. 2015;96:114-21. https://doi.org/10.1016/j.apsoil.2015.07.014

57. Hammer EC, Balogh-Brunstad Z, Jakobsen I, Olsson PA, Stipp SLS, Rilling MC. A mycorrhizal fungus grows on biochar and captures phosphorus from its surfaces. Soil Biology and Biochemistry. 2014;77:252-60. https://doi.org/10.1016/j.soilbio.2014.06.012

58. Shang X, Shang Y, Fu J, Zhan T. Nicotine significantly improves chronic stress-induced impairments of cognition and synaptic plasticity in mice. Molecular Neurobiology. 2017;54:4644-58. https://doi.org/10.1007/s12035-016-0012-2

59. Baldwin IT. An ecologically motivated analysis of plant herbivore interactions in native tobacco. Plant Physiology. 2001;127:1449-1458. https://doi.org/10.1104/pp.010762

60. Fritz C, Palacios-Rojas N, Feil R, Still M. Regulation of secondary metabolism by the Carbon-nitrogen status in tobacco: nitrate inhibits large sectors of phenylpropanoid metabolism. The Plant Journal. 2006;46:533-548. https://doi.org/10.1111/j.1365313X.2006.02715.x

61. Mardukhi B, Rejali F, Daei G, Ardakani MR, Malakouti MJ, Miransari M. Mineral uptake of mycorrhizal wheat (Triticum aestivum L.) under salinity stress. Communications in Soil Science and Plant Analysis. 2015;46:343-57. https://doi.org/ $10.1080 / 00103624.2014 .981271$

\section{Additional information}

Peer review information: Plant Science Today thanks Sectional Editor and the other anonymous reviewers for their contribution to the peer review of this work.

Reprints and permissions information is available at
https://horizonepublishing.com/journals/index.php/PST/open_access_policy Publisher's Note: Horizon e-Publishing Group remains neutral with regard to jurisdictional claims in published maps and institutional affiliations.

To cite this article: Mesbah R, Ardakani M R, Moghaddam A, Rafiei F. Yield and morpho-physiological traits of tobacco (Nicotiana tabacum L.) as affected by azotobacter, mycorrhizal symbiosis and biochar application. Plant Science Today. 2021;8(4):986-994. https://doi.org/10.14719/pst.1378

Plant Science Today, published by Horizon e-Publishing Group, is covered by Scopus, Web of Science, BIOSIS Previews, Clarivate Analytics, etc. See https://horizonepublishing.com/journals/index.php/PST/indexing_abstracting 